Braz J Med Biol Res, May 2010, Volume 43(5) 437-444

Bradysia hygida (Diptera, Sciaridae) presents two eukaryotic Elongation Factor $1 \mathrm{~A}$ gene homologues: partial characterization of the eukaryotic Elongation Factor 1A-F1 gene

J.A. Candido-Silva and N. Monesi

The Brazilian Journal of Medical and Biological Research is partially financed by
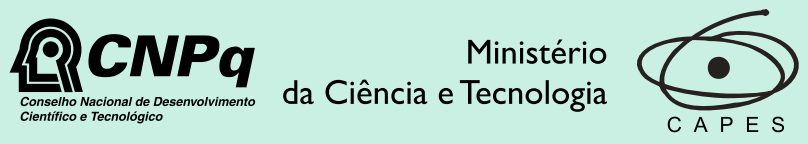

Ministério
da Educação

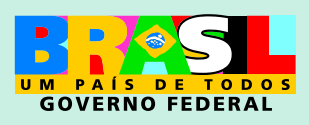

Institutional Sponsors 


\title{
Bradysia hygida (Diptera, Sciaridae) presents two eukaryotic Elongation Factor $1 A$ gene homologues: partial characterization of the eukaryotic Elongation Factor 1A-F1 gene
}

\author{
J.A. Candido-Silva and N. Monesi \\ Departamento de Análises Clínicas, Toxicológicas e Bromatológicas, \\ Faculdade de Ciências Farmacêuticas de Ribeirão Preto, \\ Universidade de São Paulo, Ribeirão Preto, SP, Brasil
}

\begin{abstract}
Elongation factor $1 \mathrm{~A}$ is a highly conserved protein that participates in translation. We report the occurrence of two genes homologous to the eukaryotic Elongation Factor $1 \mathrm{~A}$ in Bradysia hygida and describe the partial cloning and characterization of the $B$. hygida eukaryotic Elongation Factor $1 A-F 1$ (BheEF1A-F1) gene. The pattern of BheEF1A-F1 expression in the salivary gland at the end of the fourth larval instar was investigated using real-time PCR. The results showed that BheEF1A-F1 expression levels are relatively constant at the time when rapid changes in protein synthesis occur in this tissue. In situ hybridization experiments coupled to Southern blot analyses showed that the BheEF1A-F1 gene is located at position 3d of the A chromosome and a second gene homologous to eEF1A is located at position $6 \mathrm{a}$ of the $\mathrm{X}$ chromosome. Southern blot analyses showed that both the BheEF1A-F1 gene and the second gene homologous to eEF1A constitute non-amplified genes. The present results contribute to the molecular characterization of a sciarid eEF1A gene.
\end{abstract}

Key words: Eukaryotic Elongation Factor 1A; Bradysia hygida; Polytene chromosomes; Sciaridae

\section{Introduction}

The salivary gland polytene chromosomes of Diptera present RNA puffs that are sites of intense transcription. Sciarid larvae also exhibit DNA puffs, which are sites of developmentally regulated gene amplification and transcription (1-3). Several studies have shown that sciarid DNA puff gene amplification and transcription, that occur at the end of the fourth larval instar, are processes regulated by the molting hormone ecdysone (for a review, see Ref. 4).

The expansion and regression of specific DNA puffs can be related to the developmentally regulated synthesis of groups of salivary gland polypeptides (5-8). These studies led to the suggestion that the biological role of gene amplification is to provide large amounts of salivary gland proteins that are employed in the construction of the cocoon in which the larvae pupate (5-8). This suggestion was confirmed by the demonstration that polyclonal antibodies raised against either the product of DNA puff B10 (the BhB10-1 protein) or against the product of DNA puff C4 (the BhC4-1 protein) detect these polypeptides both in salivary gland extracts and saliva of larvae at the time of DNA puff formation $(9,10)$.

In addition to gene amplification and transcription, several other processes have been investigated using the Sciaridae family as a model, including mechanisms of telomere maintenance $(11,12)$, programmed cell death (13), establishment of dorsoventral polarity (14), and the immune response (15). These studies contributed to the understanding of these processes and further strengthened the view that the study of non-model organisms can contribute to the understanding of processes of general occurrence in metazoans.

Elongation factor $1 \mathrm{~A}(\mathrm{EF} 1 \mathrm{~A})$ is a protein involved in the GTP-dependent binding of an aminoacyl-tRNA to the empty A site of the ribosome. After the binding of the complex, the

Correspondence: N. Monesi, Departamento de Análises Clínicas, Toxicológicas e Bromatológicas, Faculdade de Ciências Farmacêuticas de Ribeirão Preto, Universidade de São Paulo, Avenida do Café, s/n, 14040-903 Ribeirão Preto, SP, Brasil. Fax: +55-16-3602-4725. E-mail: namonesi@fcfrp.usp.br

Received December 4, 2009. Accepted April 1, 2010. Available online April 16, 2010. Published May 14, 2010. 
GTPase activity of EF1A is activated by the ribosome and GTP hydrolysis leads to the dissociation of EF1 from the tRNA, permitting the full entrance of the tRNA into the A site (for reviews, see Refs. 16,17). Eukaryotic EF1A (eEF1A) is the most abundant intracellular protein next to actin, comprising $1-3 \%$ of the total protein content in normal growing cells $(18,19)$. The mRNA levels of eEF1A are not constant and an increase in eEF1A mRNA expression levels has been reported to occur in rapidly proliferating cells (19), whereas the down-regulation of eEF1A1 contributes to the induction of caspase-independent cell death in tetraploid vertebrate cells (20).

The amino acid sequences of eEF1A are highly conserved between species and have been widely employed in studies assessing the phylogenetic relationships in insects both among species groups and genera within (sub)-families (reviewed in Ref. 21). Both the Drosophila melanogaster and Apis mellifera genomes contain two copies of the eEF1A gene, which encode two highly similar proteins, named eEF1A-F1 and eEF1A-F2 (22-24). Previous studies in $D$. melanogaster have suggested that eEF1A-F1, which is expressed throughout development, represents a housekeeping gene that is needed in all growing cells. In contrast, the expression of the eEF1A-F2 gene peaks in the pupal stage, this being a gene that is expressed in a tissue-specific manner (23).

We describe here the molecular characterization of the eukaryotic Elongation Factor $1 \mathrm{~A}$ gene of the sciarid Bradysia hygida. Our results indicate the occurrence of two genes that are homologous to the eukaryotic Elongation Factor $1 A$ and describe the partial sequence of a cDNA coding for the $B$. hygida eukaryotic Elongation Factor $1 A-$ $\mathrm{F} 1$ (BheEF1A-F1). We show that the BheEF1A-F1 gene is located at position $3 \mathrm{~d}$ of the $\mathrm{A}$ chromosome and its levels of expression in the salivary gland at the end of the fourth larval instar are relatively constant. To our knowledge, this is the first time the existence of two eEF1A paralogs is shown in a nematoceran Dipteran.

\section{Material and Methods}

\section{Bradysia hygida}

B. hygida was maintained in the laboratory at $20^{\circ} \mathrm{C}$, and under these conditions has a life cycle of 36 days (6). From hatching to the pupal molt, the larvae go through four larval instars. The fourth instar begins on day 12 after hatching. On the 6th day of the fourth instar the eyespots appear (E1), which provide useful age markers. The E3 eyespot pattern coincides with the beginning of the process of gene amplification, when DNA puff anlage formation can be observed at several sites in the salivary glands polytene chromosomes. At the E7 eyespot stage, the first group of DNA puffs is partially open. The expansion of the second group of DNA puffs begins $12 \mathrm{~h}$ after the appearance of the E7 eyespot pattern $(E 7+12 h)$. By the time the pupal molt begins (at E7+26h), all but one of the DNA puffs are already closed. Salivary glands were dissected from fourth-instar female larvae and kept in glycerol/ethanol $(1: 1)$ at $-20^{\circ} \mathrm{C}$ until further processing.

\section{RNA extraction}

Total RNA was isolated from two pairs of salivary glands of larvae at the ages of E1, E7+4h and E7+16h. The salivary glands were washed twice in $70 \%$ ethanol to remove the glycerol and homogenized in $50 \mu \mathrm{L}$ extraction buffer (4 M guanidine thiocyanate, $50 \mathrm{mM}$ Tris- $\mathrm{HCl}, \mathrm{pH} 7.5,50$ mM EDTA, $0.5 \%$ sarcosyl, $0.72 \% 2$-mercaptoethanol). The samples were extracted once with 1 volume of phenol and a 0.2 volume of chloroform:isoamyl alcohol (49:1), followed by the addition of $1 / 10$ of the volume of $2 \mathrm{M}$ sodium acetate, $\mathrm{pH}$ 4.0 , and 1 volume of isopropyl alcohol, and kept at $-20^{\circ} \mathrm{C}$ for $16 \mathrm{~h}$. Total RNA was recovered after centrifuging at 10,000 $g$ for 30 min at $4{ }^{\circ} \mathrm{C}$, followed by two washes in $70 \%$ ethanol. After drying, the RNA was dissolved in water. Total RNA concentrations were estimated by absorbance at $260 \mathrm{~nm}$, assuming that the absorbance of $40 \mu \mathrm{g} / \mathrm{mL}$ is 1.0 .

\section{RT-PCR, primer design and partial cloning of the B. hygida eEF1A cDNA}

Total RNA samples were treated with RNase-free DNAse (Promega, USA), at a final concentration of $1 \mathrm{unit} / \mu \mathrm{g}$ RNA in DNAse buffer (40 mM Tris- $\mathrm{HCl}, \mathrm{pH}$ 8.0, $10 \mathrm{mM} \mathrm{MgSO}_{4}, 1$ $\mathrm{mM} \mathrm{CaCl} 2$ ) for $30 \mathrm{~min}$ at $37^{\circ} \mathrm{C}$. After the addition of EGTA, $\mathrm{pH} 8.0$ (final concentration $2 \mathrm{mM}$ ), DNAse was inactivated by incubating the reaction for $10 \mathrm{~min}$ at $65^{\circ} \mathrm{C}$. A mixture of $1 \mu \mathrm{g}$ total RNA, $0.25 \mu \mathrm{g}$ oligo(dT) 15 (Promega) and 0.25 $\mu \mathrm{g}$ Random Primer (Promega) was incubated at $70^{\circ} \mathrm{C}$ for $5 \mathrm{~min}$, and quickly chilled in ice, prior to the addition of Improm-II Reverse Transcriptase (Promega). Reverse transcriptase $(\mathrm{RT})$ reactions were performed according to manufacturer instructions.

The CLUSTALW program (25) was used to build a nucleotide sequence alignment containing the eEF1A nucleotide sequences of Rhynchosciara americana (GenBank accession number X66131.1), D. melanogaster (NM_058027.3), Anopheles gambiae (XM_562379.2), D. pseudoobscura (XM_001361784.2), Bombyx mori (NM_001044045.1), A. mellifera(NM_001014993.1), Aedes aegypti(DQ440206.1), and Manduca sexta (AF234571.1), and polymerase chain reaction (PCR) primers were designed based on highly conserved regions. Primer sequences are as follows: eEF1Aforward 5'-CATCGGGATCCCATCAAGAACATG-3' and eEF1A-reverse 5'-GCAATGTCTGCAGTGTGGCAATC-3'. Restriction sites for BamHI and Pstl (underlined) were introduced in the forward and reverse primers, respectively.

The PCR mixtures contained $1 / 10$ of the product of each RT reaction, $100 \mathrm{pmol}$ of each primer, $0.2 \mathrm{mM}$ dATP, 0.2 $\mathrm{mM}$ dCTP, $0.2 \mathrm{mM}$ dGTP, $0.2 \mathrm{mM}$ dTTP, $1.5 \mathrm{mM} \mathrm{MgCl}_{2}$, $20 \mathrm{mM}$ Tris- $\mathrm{HCl}, \mathrm{pH} 8.4,50 \mathrm{mM} \mathrm{KCl}$, and 2.5 units of Taq DNA Polymerase (Invitrogen, USA) and were amplified 
employing the following protocol: 1 cycle of $5 \mathrm{~min}$ at $95^{\circ} \mathrm{C}$, 40 cycles of $45 \mathrm{~s}$ at $95^{\circ} \mathrm{C}$, of $90 \mathrm{~s}$ at $56^{\circ} \mathrm{C}$, and of $90 \mathrm{~s}$ at $72^{\circ} \mathrm{C}$, followed by a final $10-$ min extension at $72^{\circ} \mathrm{C}$. An 824-bp DNA fragment was produced, gel purified, digested with BamHI and Pstl and cloned into the PBSKS+ vector (Stratagene, USA).

\section{Sequencing reactions and sequence analyses}

Dideoxynucleotide sequencing was performed using the BigDye ${ }^{\circledR}$ Terminator v3.1 Cycle Sequencing Kit (Applied Biosystems, USA). Both strands were sequenced. The sequencing reactions were performed using M13 primers (forward and reverse) and two additional internal primers (eEF2-forward: 5'-CAACATGGGATCCTTGAAGGGATG G-3' and eEF3-reverse: 5'-CGGAAACGTTCTAGACGTT GAAACC-3'). The reaction products were analyzed on an ABI Prism ${ }^{\circledR} 3100$ DNA Sequencer (Applied Biosystems). BLASTN (26) searches were performed using the NCBI non-redundant database and sequence analyses were performed using the BioEdit sequence alignment editor V7.0.9.0 (27).

\section{Quantitative SYBR ${ }^{\circledR}$ Green assay}

Five percent of the product of reverse transcription reactions (from $1 \mu \mathrm{g}$ of total salivary glands RNA) was used in real-time PCR mixtures. Each reaction (final volume of 10 $\mu \mathrm{L}$ ) contained $5 \mu \mathrm{L}$ of DyNamo SYBR ${ }^{\circledR}$ Green qPCR mix (Finnzymes, Espoo, Finland), $0.3 \mu \mathrm{M}$ of each primer and $1 \mu \mathrm{L}$ template. Real-time PCR was performed in triplicate for all samples using the Mastercycler ${ }^{\circledR}$ ep realplex system (Eppendorf, Germany) and two independent experiments were carried out. Primers were designed in order to generate 100-bp PCR fragments for both BheEF1A-F1 and the 28S ribosomal RNA (internal control). Primer sequences were as follows: BheEF1A-F1 (forward: 5'-GGTGATTGCAGTTGTT GCAT-3'; reverse: 5'-ATCAATTCTGCGCCTTTTGT-3') and 28S ribosomal RNA (forward: 5'-ATTAGCGGGGAAAGAAG ACC-3'; reverse: 5'-GCACCCGAAGGTACACATCT-3'). The amplification reactions were carried out using the following protocol: 1 cycle of $5 \mathrm{~min}$ at $95^{\circ} \mathrm{C}, 40$ cycles of $15 \mathrm{~s}$ at $95^{\circ} \mathrm{C}$, of $15 \mathrm{~s}$ at $50^{\circ} \mathrm{C}$, and of $20 \mathrm{~s}$ at $72^{\circ} \mathrm{C}$. Analysis of the melting curves revealed that a single amplified product was generated in each reaction. The data were analyzed according to the Mastercycler ${ }^{\circledR}$ ep realplex User Manual (Eppendorf) and both baseline and cycle threshold $\left(\mathrm{C}_{t}=\right.$ number of cycles needed for the fluorescence to reach a specific threshold level of detection) were set by the program. In order to determine the relative expression levels of $B h e E F 1 A-F 1$, the $C_{t}$ values obtained for BheEF1A-F1 were normalized against the values obtained for 28S rRNA and expressed as a ratio between BheEF1A-F1 and 28S rRNA.

\section{DNA extraction}

$B$. hygida salivary glands were incubated in extraction buffer (20 mM Tris-HCl, pH 7.4, 10 mM EDTA, 10\% SDS, 1 $\mathrm{mg} / \mathrm{mL}$ proteinase $\mathrm{K}$ ) at room temperature for $30 \mathrm{~min}$. After 2 phenol:chloroform extractions and 1 chloroform extraction, DNA was precipitated in ethanol and resuspended in TE (10 mM Tris- $\mathrm{HCl}, 1 \mathrm{mM}$ EDTA, pH 8.0). DNA concentrations were determined by fluorometry using bisbenzimide (Hoescht 33258 from Sigma-Aldrich, USA).

\section{Southern blot hybridization}

Ten micrograms of salivary gland genomic DNA was treated with distinct restriction enzymes according to manufacturer instructions (New England BioLabs Inc., USA). After digestion, the DNA samples were treated with RNase A $(20$ $\mu \mathrm{g}$, Sigma-Aldrich) for $30 \mathrm{~min}$ at $37^{\circ} \mathrm{C}$, and run on $0.8 \%$ agarose gels in TAE buffer ( $40 \mathrm{mM}$ Tris-acetate, $1 \mathrm{mM}$ EDTA, $\mathrm{pH}$ 8.0), for $16 \mathrm{~h}$ at $22 \mathrm{~V}$. Southern blotting was performed on nylon membranes (Amersham Hybond ${ }^{\mathrm{TM}}-\mathrm{N}^{+}$) according to membrane manufacturer instructions (GE Healthcare, UK). BheEF1A-F1 cDNA fragment labeling, hybridization, post-hybridization washes, and detection were performed using the Amersham Gene Images AlkPhos Direct Labeling and Detection System (GE Healthcare) according to manufacturer instructions.

\section{In situ hybridization}

Larval salivary glands were dissected in phosphatebuffered saline (PBS; $130 \mathrm{mM} \mathrm{NaCl}, 7 \mathrm{mM} \mathrm{Na} \mathrm{HPO}_{4}, 3$ $\mathrm{mM} \mathrm{NaH}_{2} \mathrm{PO}_{4}, \mathrm{pH}$ 7.0). The anterior region of the salivary glands (S1 region) was removed and placed on a $2 \%$ gelatin-treated slide in a drop of $45 \%$ acetic acid for 2 min. A fresh drop of $45 \%$ acetic acid was added and the salivary glands were covered with a coverslip and tapped with a forceps in order to spread the chromosomes. The coverslip was removed after freezing in liquid nitrogen, and the slide immediately plunged into absolute ethanol kept at $0^{\circ} \mathrm{C}$. The preparations were stored for up to 2 days in ethanol at $4^{\circ} \mathrm{C}$ before processing. Probes were labeled with digoxigenin-dUTP (Roche, Switzerland) by random primer reaction. In situ hybridization was performed according to the protocol of the Berkeley Drosophila Genome Project (http://www.fruitfly.org/about/methods/cytogenetics.html), with the following modifications: after incubation with antidigoxigenin-POD (Roche, diluted 1:50) for $1 \mathrm{~h}$, the preparations were washed three times in PBS-T containing $0.1 \%$ Triton $\mathrm{X}-100$, for 5 min each time, followed by incubation with peroxidase-anti-peroxidase (Sigma-Aldrich, 1:100) for $2 \mathrm{~h}$ and washed again three times in PBS-T for $5 \mathrm{~min}$ each time. Enzyme activity was detected by incubating the slides with $0.5 \mathrm{mg} / \mathrm{mL} 3,3$ '-diaminobenzidine tetrahydrochloride (Sigma-Aldrich) in PBS containing $0.01 \%$ hydrogen peroxide for $10 \mathrm{~min}$. The slides were washed with PBS-T, stained with $0.05 \%$ toluidine blue and mounted in PBS-T/glycerol (1:1). The images were recorded using an Ortholux 2 Pol BK Leitz microscope (Leitz, Germany), equipped with a Leica EC3 camera system (Leica Microsystems, Germany) and were analyzed with the Las EZ version 1.4 .0 software 
(Leica Microsystems). Alternatively, the images were recorded using an Axioskop 40 microscope (Zeiss, Germany) equipped with an AxionCam MRc5 camera system (Zeiss) and were analyzed with the Axion Vision version 4.6 software (Zeiss).

\section{Results and Discussion}

\section{Cloning of a BheEF1A cDNA fragment}

In order to clone the eEF1A gene of $B$. hygida, we designed primers corresponding to highly conserved regions present in the nucleotide sequences of the eEF1A of 8 insect species (see Material and Methods). A single 824-bp RT-PCR product was obtained from RNA extracted from salivary glands at the late E7 stage. This 824-bp fragment was cloned and sequenced.

The nucleotide sequence of the cloned cDNA fragment was used in a similarity search performed with the BLASTN program (26). The sequence of the BheEF1A cDNA fragment presents high identity with the eEF1A mRNA sequences of different species (up to $87 \%$ identity with an $E$ value $<0.01$ ). Furthermore, the cloned sequence presents $86 \%$ identity with the eEF1A of $R$. americana, the only sciarid eEF1A mRNA sequence currently available in the nucleotide database of the National Center for Biotechnology Information (NCBI).

The deduced amino acid sequence of the longest open reading frame, which spans the entire cloned cDNA fragment, is shown in Figure 1. Multiple alignments of the 266-amino acid deduced sequence with eEF1A amino acid deduced sequences of other insect species (Figure 1) revealed significant similarity $(95,93,93,91$, and $89 \%$ identity) with the sequences of $D$. melanogaster (eEF1A-F1), $R$. americana, A. mellifera (eEF1A-F2), D. melanogaster (eEF1A-F2), and A. mellifera (eEF1A-F1), respectively. The cloned BheEF1A presents higher similarity to the eEF1A-F1 variant of $D$. melanogaster $(95 \%)$ than to the eEF1A-F2 variant of $D$. melanogaster $(91 \%)$. The sequence obtained was deposited in GenBank (accession number GQ119627) and named eukaryotic Elongation Factor $1 A-F 1$ of $B$. hygida (BheEF1A-F1), according to the nomenclature proposed in Ref. 28.

EF1A proteins consist of three structural domains: domain I or $\mathrm{G}$ domain, domain II, and domain III. Domain I ( $G$ domain) is approximately 200 residues long, is responsible for binding either GTP or GDP and is related to the GTPase domains of other G proteins. Domains II and III both contain approximately 100 residues and are $\beta$ barrels. These domains are in the same relative orientation and might act as a single rigid unit during hydrolysis of GTP $(16,17)$. EF1A domains I and II are both present in the BheEF1A-F1 deduced amino acid sequence (Figure 1). The consensus GTP-binding motif (NKMD) is found in domain I of BheEF1A between amino acids 55-58 (Figure 1). The observation of sequence conservation is not surprising, given the fact that recent structural studies have revealed that the structures of EF1A are highly conserved between archaea and bacteria (29).

\section{BheEF1A-F1 expression at the end of the fourth larval instar of $B$. hygida}

The end of the fourth larval instar of $B$. hygida has been previously characterized as a developmental time during which dynamic and abundant protein synthesis occurs in the salivary glands $(6,7)$. After an initial period of nine days during which a characteristic set of polypeptides are synthesized, the salivary glands carry out two successive programs of specialized protein synthesis that last about $12 \mathrm{~h}$ each. The temporal coincidence between these two programs of protein synthesis and DNA puff formation has led to the suggestion that the newly synthesized proteins are the products of DNA puffs (6). In this context, we have investigated the pattern of expression of BheEF1A-F1 mRNA at three different ages at the end of the fourth larval instar: E1 (first period of synthesis), E7+4h (second period of synthesis) and E7+16h (third period of synthesis).

BheEF1A-F1 mRNA relative expression levels were determined using real-time PCR. The $\mathrm{C}_{\mathrm{t}}$ values obtained for BheEF1A-F1 were normalized against the $C_{t}$ values obtained for 28S rRNA, which was employed as an internal control. Analysis of the dissociation curves suggested that a single eEF1A isoform is expressed at the end of the fourth instar. Real-time PCR results revealed that BheEF1A-F1 expression occurs at similar levels in all ages analyzed (E1: $2.295 \pm 0.07 ; E 7+4 h: 2.29 \pm 0.19 ; E 7+16 h: 2.075 \pm 0.47$ ). Although the protein synthesis profiles undergo drastic changes at the end of the fourth larval instar (6) and a 28-fold increase in secretory protein synthesis occurs at age E7 (7), BheEF1A-F1 expression levels at the ages examined showed no significant variations during the end of the fourth larval instar.

In $D$. melanogaster, the eEF1A-F1 gene has been described as the housekeeping gene that gives rise to the elongation factor needed in all growing cells, whereas the eEF1A-F2 gene is expressed in a developmentally regulated manner (23). The detection of constant BheEF1A-F1 mRNA expression levels during the end of the fourth larval instar reinforces the suggestion that the cloned cDNA corresponds to the eEF1A-F1 isoform and to the eEF1A-F1 housekeeping gene. A similar situation has been described for the two human isoforms characterized (eEF1A1 and eEF1A2). The eEF1A1 isoform is highly expressed in tissues displaying elevated rates of protein synthesis and cell proliferation, whereas the eEF1A2 isoform is expressed in tissues in which the majority of the cells are fully differentiated and are characterized by reduced or no cell division (30).

\section{Genomic characterization of the BheEF1A gene}

In order to determine the cytogenetic location of the BheEF1A-F1 gene, we performed in situ hybridization in 
BheEF $1 \mathrm{~d}-\mathrm{F} 1$ RaeEF 1ì DmeEF $1 \mathrm{a}-\mathrm{F} 1$ DmeEF $1 \mathrm{~d}-\mathrm{F} 2$ ìmeEF $1 \mathrm{~d}-\mathrm{F} 2$ dymeEF $1 \dot{d}-F 1$

BheEF $1 \grave{d}-F 1$ RaeEF 1j DmeEF $1 \mathrm{~d}-F 1$ DmeEF $1 \mathrm{~d}-\mathrm{F} 2$ DymeEF $1 \mathrm{~d}-\mathrm{F} 2$ ìmeEF $1 \mathrm{~d}-\mathrm{F} 1$

BheEF $1 \mathrm{~d}-\mathrm{F} 1$ RaeEF 1j DMeEF $1 \mathrm{~A}-\mathrm{F} 1$ DMeEF $1 \mathrm{~d}-\mathrm{F} 2$ MmeEF $1 \mathrm{~d}-\mathrm{F} 2$ pmeEF $1 \mathrm{~d}-\mathrm{F} 1$

BheEF $1 \mathrm{~d}-\mathrm{F} 1$ RaeEF 1 ì DmeEF $1 \mathrm{~d}-\mathrm{F} 1$ DMeEF $1 \mathrm{~A}-\mathrm{F} 2$ ÀmeEF $1 \mathrm{~A}-\mathrm{F} 2$ ymeEF $1 \mathrm{~d}-\mathrm{F} 1$

BheEF $1 \mathrm{~d}-\mathrm{F} 1$ RaeEF 1 ì DMeEF $1 \mathrm{~d}-\mathrm{F} 1$ DmeEF 1 1 -F2 dye $\mathrm{EF} 1 \mathrm{~A}-\mathrm{F} 2$ İmeEF $1 \grave{d}-F 1$

BheEF $1 \mathrm{~A}-\mathrm{F} 1$ RaeEF 1j DMeEF $1 \mathrm{~d}-\mathrm{F} 1$ DmeEF $1 \mathrm{~A}-\mathrm{F} 2$ dMeEF $1 \mathrm{~A}-\mathrm{F} 2$ imeEF $1 \mathrm{~d}-\mathrm{F} 1$

\begin{tabular}{|c|c|c|c|c|c|c|c|}
\hline$\left.\cdots\right|_{5} \ldots \mid$ & $\underset{15}{\cdots \mid} \cdots \mid$ & $\underset{25}{\cdots 1} \cdots 1$ & $\underset{35}{\cdots}$ & $\underset{45}{\cdots \mid}$ & $\left.\cdots\right|_{55} \cdots \mid$ & $\underset{65}{\cdots \mid} \cdots \mid$ & $\underset{75}{\cdots \mid}$ \\
\hline
\end{tabular}

MGKEKIHINI WVIGHVDSGK STTTGHLIYK CGGIDKRTIE KFEKE AOEMG KGSFKYATVL DKLKAERERG ITIDIALUKF MGKEKIHINI VUIGHVDSGK STTTGHLIYK CGGIDKRTIE KFEKEAQEMG KGSFKYATVL DKLKAERERG ITIDIMLWKF MGKEKIHINI VVIGHUDSGK STTTGHLIYK CGGIDKRTIE KFEKEAQEMG KGSFKYALVL DKLKAERERG ITIDIALUKF

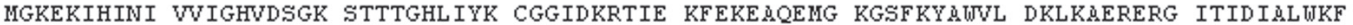

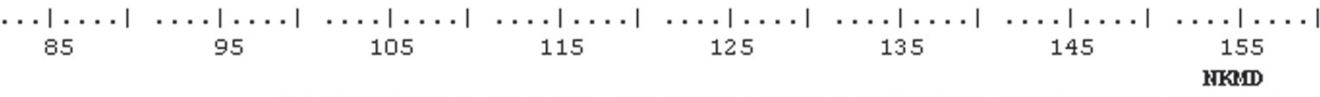
ETÀKYYTII DAPGHRDFIK NMITGTSQÀD CAVLIVAXGT GEFEAGISKN GQTREHALLA FTLGVKQLIV GVMKMSTEP ETAKYYVTI DAPGHRDFIK NMITGTSQAD CAVLIVAMGT GEFEAGISKN GQTREHALLA FTLGVKQLIV GVMKASSEP ETSKYYVTII DAPGHRDFIK NMITGTSQLD CAVLIVASGT GEFEMGISKN GQTREHALLA FTLGVKQLIV GVIKADSTEP ETSKYYVTII DAPGHRDFIK NMITGTSQAD CAVLIVAAGT GEFEAGISKN GQTREHALLA FTLGVKQLIV GVNKMDSTEP ETAKYYVTII DAPGHRDFIK NMITGTSQÄD CAVLIVAAGI GEFEAGISKN GQTREHALLA FTLGVKQLIV GVMKMNTDP

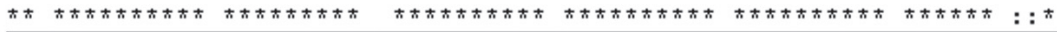

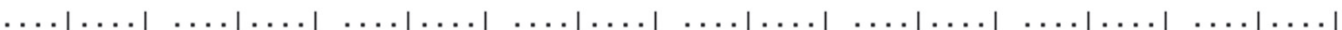
$\begin{array}{llllllll}165 & 175 & 185 & 195 & 205 & 215 & 225 & 235\end{array}$ PFSENRYEE I KKEVSSYIKK IGMNPAMVAF VPISGUHGDN MLEPSTNMPU FKGUKVERKE GNAEGKCLIE גLDAILPPSR

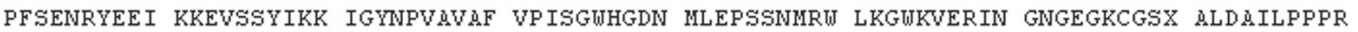
PYSEARYEE I KKEVSSYIKK IGYNPAXVAF VPISGUHGDN MLEPSTNMPU FKGUKVERKE GNADGKTLID ALDALILPPAR PYSE ARYEEI KKEVSSYIKK IGYNP ASVAF VPISGUHGDN MLEPSEKMPU FKGUSVERKE GKAEGKCLID ALDAILPPQR PYSETRFEEI KKEVSSYIKK IGYNP ALVAF VPISGUHGDN MLEVSSKMPU FKGUTVERKE GKVEGKCLIE ALDAILPPTR PYSE ARFEEI KKEVSSYIKK IGYNTASVAF VPISGUHGDN MLEPSPKTPW YKGUKVERKD GNDDGKTLIE ALDAILPPSR

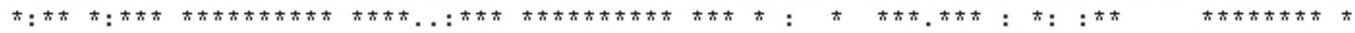

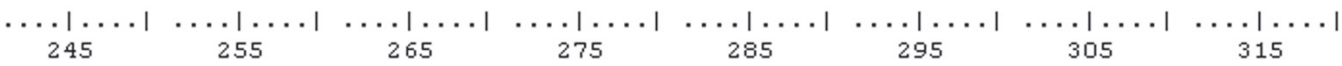
PTDKALRLPL QDVYKIGGIG TVPVGRVETG VLKPGTVVVF APANTTTEVK SVEMHHEALT EAVPGDNVGF NVKNVSVKEL PTDQALRLPL PDVYKIGGIG TVPVGRLETG ILKPGTVWF APANITTEVK SVEMHHEALT EAVPGDNVGF NVKNVSVKEL PTDKDLRLPL ODVYKIGGIG TVPVGRVETG VLKPGTVVNF AP WNITTEVK SVEMHHE LLO EAUPGDNVGF NUKNUSVKEL PTDKPLRLPL QDVYKIGGIG TVPVGRVETG LLKPGMVNNF APVNLVTEVK SVEMHHEALT EAMPGDNVGF NVKNVSVKEL PTDKALRLPL QDVYKIGGIG TVPVGRVETG VLKPGNVTF AP AGLTTEVK SVEMHHEALQ EAVPGDNVGF NVKNVSVKEL PTDKALRLPL QDVYKIGGIG TVPVGRVETG ILKPGMLVTF APALLTTEVK SVEMHHE ALT EALPGDNVGF NVKNISVKEL

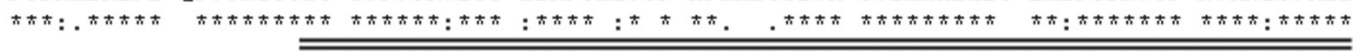

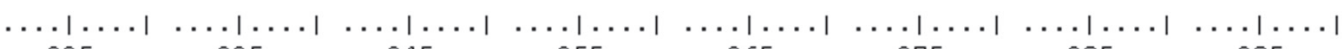
$\begin{array}{llllllll}325 & 335 & 345 & 355 & 365 & 375 & 385 & 395\end{array}$

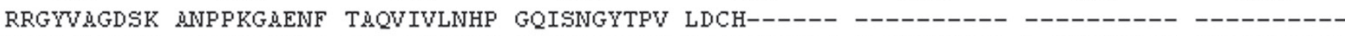

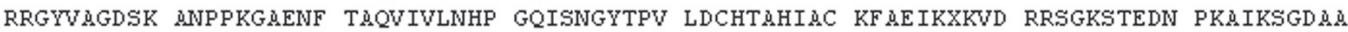

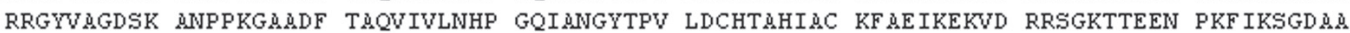

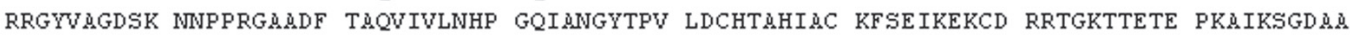

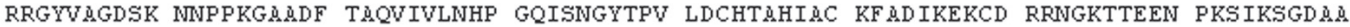

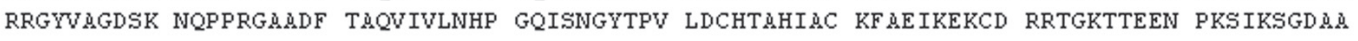

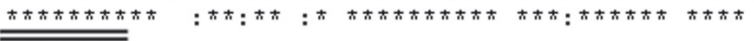

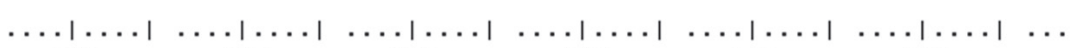

$\begin{array}{llllll}405 & 415 & 425 & 435 & 445 & 455\end{array}$

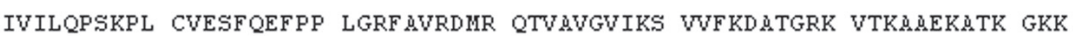
IVNLVPSKPL CVEAFQEFPP LGRF AVRDMR QTVAVGVIKA VNFKD ASGGK VTKÄEKATK GKK IIVLVPSKPL CVESFQEFPP LGRFAVRDMR QTVAVGVIKS VNFKETTSGK VTKAAEKAQK KKIVMLVPSKPM CAEAFQEFPP LGRF AVRDMR QTVAVGVIKA VTFKD-AMGK VTKAXEKAQK KKIVMLQPTKPM CVEAFQEFPP LGRFDVRDMR QTVAVGVIKS VTFKD-TQGK VTKADEKAQK KK-

Figure 1. Multiple alignment of eEF1A deduced amino acid sequences. The BheEF1A-F1 deduced amino acid sequence (GenBank accession number GQ119627) was aligned with the deduced eEF1A amino acid sequences of Rhynchosciara americana (RaeEF1A, CAA46922.1), Drosophila melanogaster (DmeEF1A-F1, NP_477375.1), D. melanogaster (DmeEF1A-F2, NP_524611.1), Apis mellifera (AmeEF1A-F2, NP_001014993.1), and A. mellifera (AmeEF-1A-F1, NP_001011628.1) using the CLUSTALW program (25). The consensus GTP-binding motif (NKMD) is indicated in bold. The domain I or G domain is underlined. The domain II is double-underlined. 
salivary gland polytene chromosomes of fourth-instar larvae. As shown in Figure 2, the BheEF1A-F1 probe hybridizes in two different chromosomal regions: the $3 d$ region of the A chromosome (Figure $2 \mathrm{~A}$ ) and the 6 a region of the $\mathrm{X}$ chromosome (Figure 2B). Labeling in the A3d region was always detected, whereas labeling in the $\mathrm{X} 6 \mathrm{a}$ region was detected in the majority of the chromosomes analyzed. Extensive examination of four independent experiments did not reveal any labeling in the $\mathrm{B}$ or $\mathrm{C}$ chromosome (data not
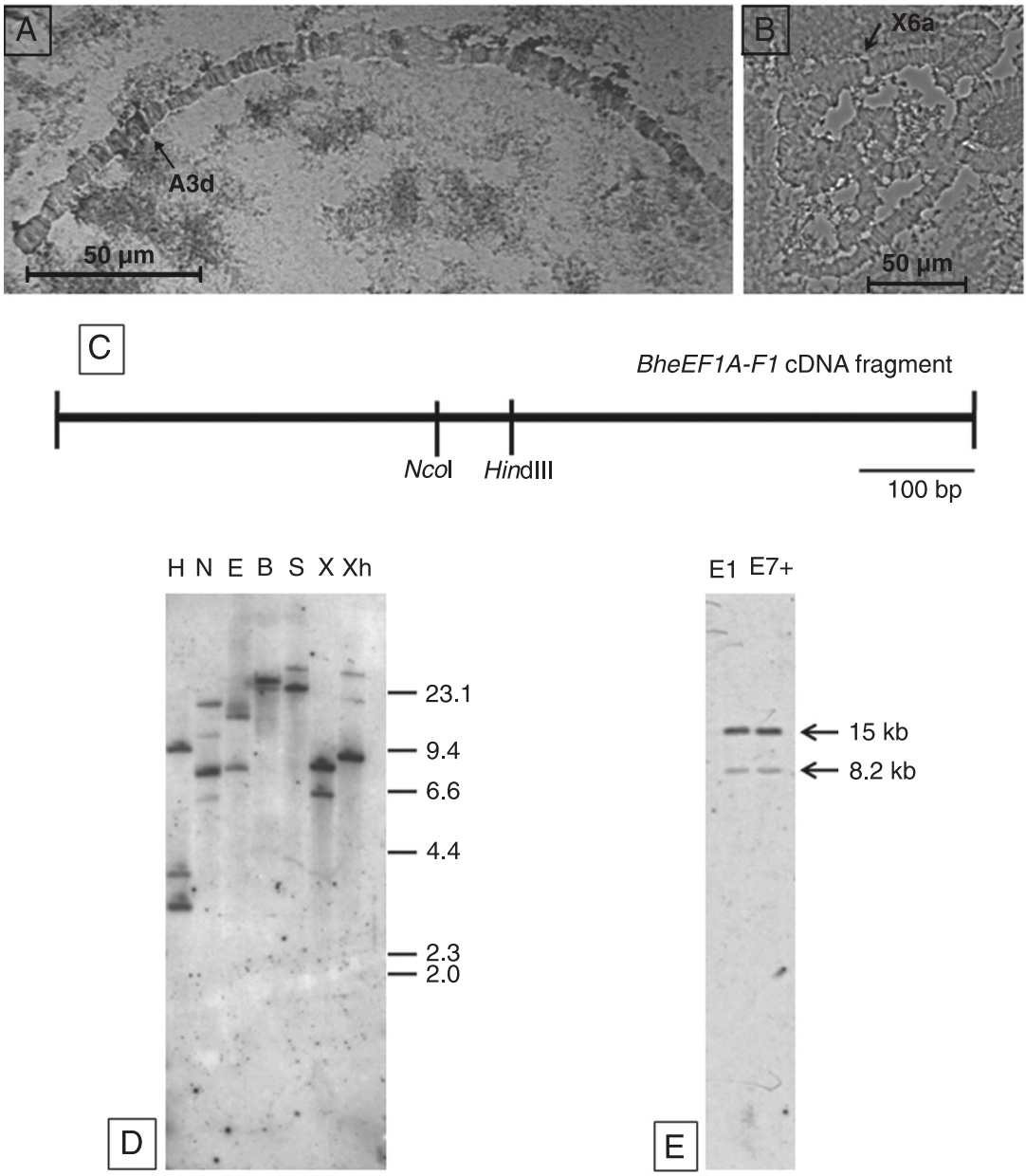

Figure 2. Cytogenetic mapping and Southern blot characterization of BheEF1A. $A, B$, In situ hybridization. Salivary gland polytene chromosomes were hybridized with a digoxigenin-labeled BheEF1A-F1 cDNA fragment and counterstained with Toluidine blue. The arrows point to the $A 3 d(A)$ and the $X 6 a(B) l o c i$, in which the product of the peroxidase reaction was detected. $C$, Restriction map of the BheEF1A-F1 CDNA fragment. Both HindIII (nucleotide 397) and $\mathrm{Ncol}$ (nucleotide 333) sites are shown. D, Southern blot containing identical amounts of genomic DNA extracted from salivary glands at late E7 and digested with different enzymes, was hybridized with the BheEF1A-F1 cDNA fragment, followed by detection with the CDPstar reagent. The restriction enzymes employed are indicated on top of the blot: HindIII (H), Ncol (N), EcoRI (E), BamHI (B), Sall (S), Xbal (X), and Xhol $(\mathrm{Xh}) . E$, Southern blot containing identical amounts of EcoRI-digested DNA extracted from salivary glands at ages $\mathrm{E} 1$ and late $\mathrm{E} 7(\mathrm{E} 7+)$, after hybridization with the BheEF1A-F1 cDNA fragment, followed by detection with the CDPstar reagent. shown). Since the hybridization signal in the A3d region was more intense, we propose that this region corresponds to the eEF1A gene.

In order to extend the characterization of the BheEF1A$F 1$ gene, a Southern blot containing $10 \mu \mathrm{g}$ salivary gland genomic DNA of larvae at late E7 $(E 7+)$, digested with seven different restriction enzymes, was hybridized to the BheEF1A-F1 CDNA. As can be observed in Figure 2D, the BheEF1A-F1 probe detected four Ncol fragments, three genomic fragments in both HindIII and Xhol digestions, and two genomic fragments in the EcoRI, BamHI, Sall, and $X$ bal digestions. We consistently detected genomic fragments of different labeling intensities regardless of the restriction enzyme employed (Figure 2D). The BheEF1A-F1 cDNA fragment contains both an HindIII and an Ncol restriction site (Figure 2C) and at least three genomic fragments were detected when either restriction enzyme was used to digest the DNA. In the case of the remaining five enzymes tested, for which there are no restriction sites in the probe, we detected at least two genomic fragments. We suggest that the more intensely labeled fragments in the Southern blot correspond to genomic fragments containing the BheEF1A-F1 gene and we attribute the weaker signals to the detection of a second gene that is similar to the BheEF1A-F1 gene.

Two copies of the eEF1A gene are also found in different insect orders. D. melanogaster and A. mellifera both contain two copies of the eEF1A gene encoding highly similar proteins that differ both in sequence and exon and in intron organization. The D. melanogastereEF1A-F1 gene consists of two exons separated by an intron. In contrast, the $D$. melanogaster eEF1A-F2 gene is organized into five exons separated by four introns $(22,23)$. In $A$. mellifera the eEF1A-F1 gene is closely related to the $D$. melanogaster EEF1A-F2 gene (31) and is organized into three exons 
separated by two introns (24). The A. mellifera eEF1A-F2 gene shows high similarity to the $D$. melanogastereEF1A-F1 gene and presents four exons separated by three introns (24). The existence of two copies of eEF1A genes in both D. melanogaster (Diptera) and A. mellifera (Hymenoptera), together with the recently found eEF1A gene duplication in Xyleborini (Coleoptera) (32), suggests that eEF1A duplication might be more widespread in the holometabolous insect orders. Previous studies have suggested that the eEF1A gene was duplicated in parallel in the Diptera and in the Hymenoptera (24). Taken together, these data further support the existence of two paralogous copies of the eEF1A gene in the nematoceran Dipteran B. hygida.

Sciarid DNA puffs have been previously characterized as genomic regions in which developmentally regulated gene amplification occurs (33-38). The only DNA puff-forming regions found on chromosomes $A$ and $X$ constitute the $A 14$ and $X 4$ regions, respectively (6). Therefore, the identification of both the $\mathrm{A} 3 \mathrm{~d}$ and $\mathrm{X} 6 \mathrm{a}$ regions in the in situ hybridization experiments revealed that the BheEF1A gene is not located in DNA puff-forming regions. In order to investigate whether the BheEF1A-F1 gene is amplified during the end of the fourth larval instar, a Southern blot containing identical amounts $(10 \mu \mathrm{g})$ of EcoRI-digested salivary gland genomic DNA of larvae at age E1 (before gene amplification) and late E7 (after gene amplification) was hybridized to the BheEF1A-F1 probe (Figure 2E). In both cases two genomic fragments were identified. Regardless of the age analyzed, both samples showed that the hybridization signal of the $15-\mathrm{kb}$ fragment was stronger than that of the 8.2$\mathrm{kb}$ fragment. In addition, the intensity of the hybridization signals for each fragment was closely similar when both samples, E1 and E7+, were compared (Figure 2E). These

\section{References}

1. Stocker AJ, Yokosawa J, Soares MA, Cadavid EO. DNA replication and amplification during the final cycle of polyteny in sciarid gland chromosomes and their control by ecdysone. Ciência e Cultura 1996; 48: 306-312.

2. Gerbi SA, Liang C, Wu N, DiBartolomeis SM, Bienz-Tadmor $\mathrm{B}$, Smith HS, et al. DNA amplification in DNA puff II/9A of Sciara coprophila. Cold Spring Harb Symp Quant Biol 1993; 58: 487-494

3. Lara FJ, Stocker AJ, Amabis JM. DNA sequence amplification in sciarid flies: results and perspectives. Braz J Med Biol Res 1991; 24: 233-248.

4. Monesi N, Candido-Silva JA, Paçó-Larson ML, de Almeida JC. Regulation of sciarid DNA puffs by ecdysone: mechanisms and perspectives. In: Smagghe G (Editor), Ecdysone: structures and functions. 1st edn. Netherlands: Springer Science + Business Media B.V.; 2009. p 165-183.

5. Winter CE, de Bianchi AG, Terra WR, Lara FJS. The giant DNA puffs of Rhynchosciara americana code for polypeptides of the salivary gland secretion. J Insect Physiol 1977; 23: 1455-1459. results reveal that at $E 7+$, a developmental time when the amplification process has already occurred in the DNA puff-forming regions, the number of copies of the eEF1A gene is the same as before the gene amplification process, age (E1), and therefore constitutes a non-amplified gene. These results agree with previous experiments using the $R$. americana eEF1A gene as a non-amplified control gene to estimate the amplification levels in both the $B$. hygida DNA puff C4 amplified domain and the $R$. americana C3 amplified domain $(39,40)$.

Our results contribute to the characterization of the eEF1A of $B$. hygida, which constitutes the second sciarid eEF1A sequence to be deposited in the public databases. The availability of this cDNA sequence coupled to the data suggesting the existence of two paralogs in B. hygida, a nematoceran Dipteran, will contribute to future insect phylogeny studies.

\section{Acknowledgments}

The authors thank Dr. Maria Helena Goldman of the Laboratório de Biologia Molecular de Plantas, Faculdade de Filosofia, Ciências e Letras de Ribeirão Preto, Universidade de São Paulo, for nucleotide sequencing. We thank Dr. R.J. Ward for helpful suggestions during the preparation of the manuscript. Research supported by FAPESP (\#2006/52600-8), CNPq (\#479979/2008-1) and the Pró-Reitoria de Pesquisa of the University of São Paulo (\#2008.1.10001.1.7). J.A. Candido-Silva is the recipient of a post-doctoral fellowship from FAPESP (\#2006/06081-9). $\mathrm{N}$. Monesi is the recipient of a research fellowship from CNPq (\#307400/2006-9).
6. Laicine EM, Alves MA, de Almeida JC, Rizzo E, Albernaz WC, Sauaia H. Development of DNA puffs and patterns of polypeptide synthesis in the salivary glands of Bradysia hygida. Chromosoma 1984; 89: 280-284.

7. de-Almeida JC. A 28-fold increase in secretory protein synthesis is associated with DNA puff activity in the salivary gland of Bradysia hygida (Diptera, Sciaridae). Braz J Med Biol Res 1997; 30: 605-614.

8. Winter CE, de Bianchi AG, Terra WR, Lara FJS. Relationships between newly synthesized proteins and DNA puff patterns in salivary glands of Rhynchosciara americana. Chromosoma 1977; 61: 193-206.

9. Fontes AM, Conacci ME, Monesi N, de Almeida JC, PaçóLarson ML. The DNA puff BhB10-1 gene encodes a glycinerich protein secreted by the late stage larval salivary glands of Bradysia hygida. Gene 1999; 231: 67-75.

10. Monesi N, Silva JA Jr, Martins PC, Teixeira AB, Dornelas EC, Moreira JE, et al. Immunocharacterization of the DNA puff BhC4-1 protein of Bradysia hygida (Diptera: Sciaridae). Insect Biochem Mol Biol 2004; 34: 531-542. 
11. Gorab E. Reverse transcriptase-related proteins in telomeres and in certain chromosomal loci of Rhynchosciara (Diptera: Sciaridae). Chromosoma 2003; 111: 445-454.

12. Madalena CR, Gorab E. A chromosome end satellite of Rhynchosciara americana (Diptera: Sciaridae) resembling nematoceran telomeric repeats. Insect Mol Biol 2005; 14: 255-262.

13. Simon CR, de Almeida JC. Programmed cell death in Bradysia hygida (Diptera, Sciaridae) salivary glands presents apoptotic features. Genesis 2004; 40: 22-31.

14. Carvalho JC, Rocha DN, Bruno RV, Vanario-Alonso CE, Abdelhay E. Expression of dorsal-ventral genes during early development of Rhynchosciara americana embryos. Braz J Med Biol Res 2005; 38: 27-31.

15. Candido-Silva JA, Zanarotti GM, Gallina AP, de Almeida JC. Developmental regulation of BhSGAMP-1, a gene encoding an antimicrobial peptide in the salivary glands of Bradysia hygida (Diptera, Sciaridae). Genesis 2007; 45: 630-638.

16. Andersen GR, Nissen P, Nyborg J. Elongation factors in protein biosynthesis. Trends Biochem Sci 2003; 28: 434-441.

17. Noble CG, Song H. Structural studies of elongation and release factors. Cell Mol Life Sci 2008; 65: 1335-1346.

18. Slobin LI. The role of eucaryotic factor Tu in protein synthesis. The measurement of the elongation factor Tu content of rabbit reticulocytes and other mammalian cells by a sensitive radioimmunoassay. Eur J Biochem 1980; 110: 555-563.

19. Condeelis J. Elongation factor 1 alpha, translation and the cytoskeleton. Trends Biochem Sci 1995; 20: 169-170.

20. Kobayashi Y, Yonehara S. Novel cell death by downregulation of eEF1A1 expression in tetraploids. Cell Death Differ 2009; 16: 139-150.

21. Caterino MS, Cho S, Sperling FA. The current state of insect molecular systematics: a thriving Tower of Babel. Annu Rev Entomol 2000; 45: 1-54.

22. Walldorf U, Hovemann B, Bautz EK. F1 and F2: Two similar genes regulated differently during development of Drosophila melanogaster. Proc Natl Acad Sci U S A 1985; 82: 5795-5799.

23. Hovemann B, Richter S, Walldorf U, Cziepluch C. Two genes encode related cytoplasmic elongation factors 1 alpha (EF1 alpha) in Drosophila melanogaster with continuous and stage specific expression. Nucleic Acids Res 1988; 16 : 3175-3194.

24. Danforth BN, Ji S. Elongation factor-1 alpha occurs as two copies in bees: implications for phylogenetic analysis of EF-1 alpha sequences in insects. Mol Biol Evol 1998; 15: 225-235.

25. Thompson JD, Higgins DG, Gibson TJ. CLUSTAL W: improving the sensitivity of progressive multiple sequence alignment through sequence weighting, position-specific gap penalties and weight matrix choice. Nucleic Acids Res 1994; 22: 4673-4680.

26. Altschul SF, Gish W, Miller W, Myers EW, Lipman DJ. Basic local alignment search tool. J Mol Biol 1990; 215: 403-410.
27. Hall TA. BioEdit: a user-friendly biological sequence alignment editor and analysis program for Windows 95/98/NT. Nucleic Acids Symp Ser 1999; 41: 95-98.

28. Ad Hoc Nomenclature Subcommittee Report. Prokaryotic and eukaryotic translation factors. Biochimie 1996; 78: 11191122.

29. Vitagliano L, Masullo M, Sica F, Zagari A, Bocchini V. The crystal structure of Sulfolobus solfataricus elongation factor 1 alpha in complex with GDP reveals novel features in nucleotide binding and exchange. EMBO J 2001; 20: 53055311.

30. Knudsen SM, Frydenberg J, Clark BF, Leffers H. Tissuedependent variation in the expression of elongation factor-1 alpha isoforms: isolation and characterisation of a cDNA encoding a novel variant of human elongation-factor 1 alpha. Eur J Biochem 1993; 215: 549-554.

31. Walldorf U, Hovemann BT. Apis mellifera cytoplasmic elongation factor 1 alpha (EF-1 alpha) is closely related to Drosophila melanogaster EF-1 alpha. FEBS Lett 1990; 267 : 245-249.

32. Jordal $\mathrm{BH}$. Elongation factor 1 alpha resolves the monophyly of the haplodiploid ambrosia beetles Xyleborini (Coleoptera: Curculionidae). Insect Mol Biol 2002; 11: 453-465.

33. Paçó-Larson ML, de Almeida JC, Edström JE, Sauaia H. Cloning of a developmentally amplified gene sequence in the DNA Puff C4 of Bradysia hygida (Diptera, Sciaridae) salivary glands. Insect Biochem Mol Biol 1992; 22: 439-446.

34. Wu N, Liang C, DiBartolomeis SM, Smith HS, Gerbi SA. Developmental progression of DNA puffs in Sciara coprophila: amplification and transcription. Dev Biol 1993; 160: 73-84.

35. Santelli RV, Machado-Santelli GM, Pueyo MT, NavarroCattapan LD, Lara FJ. Replication and transcription in the course of DNA amplification of the C3 and C8 DNA puffs of Rhynchosciara americana. Mech Dev 1991; 36: 59-66.

36. Santelli RV, Siviero F, Machado-Santelli GM, Lara FJ, Stocker AJ. Molecular characterization of the B-2 DNA puff gene of Rhynchosciara americana. Chromosoma 2004; 113: 167-176.

37. Fontes AM, de-Almeida JC, Edström JE, Paçó-Larson ML. Cloning of a B10 DNA puff sequence developmentally amplified and expressed in the salivary gland of Bradysia hygida. Braz J Med Biol Res 1992; 25: 777-780.

38. Glover DM, Zaha A, Stocker AJ, Santelli RV, Pueyo MT, De Toledo SM, et al. Gene amplification in Rhynchosciara salivary gland chromosomes. Proc Natl Acad Sci U S A 1982; 79: 2947-2951.

39. Monesi N, Fernandez MA, Fontes AM, Basso LR Jr, Nakanishi $\mathrm{Y}$, Baron B, et al. Molecular characterization of an $18 \mathrm{~kb}$ segment of DNA puff C4 of Bradysia hygida (Diptera, Sciaridae). Chromosoma 1995; 103: 715-724.

40. Yokosawa J, Soares MA, Dijkwel PA, Stocker AJ, Hamlin JL, Lara FJ. DNA replication during amplification of the C3 puff of Rhynchosciara americana initiates at multiple sites in a 6 kb region. Chromosoma 1999; 108: 291-301. 